\title{
Pengaruh Teknik Snags Mulligan Terhadap Aktivitas Fungsional Leher Penjahit
}

\author{
Anita Faradila Rahim", Atika Yulianti, Ardi Azis Anhar \\ Program Studi Fisioterapi, Fakultas Ilmu Kesehatan, Unversitas Muhammadiyah Malang \\ *Korespondensi : Anitafaradilla@umm.ac.id
}

\begin{abstract}
ABSTRAK
Perubahan ekonomi yang terjadi sekarang ini menyebabkan sektor industri selalu berupaya dan berlomba-lomba untuk meningkatkan produksi. Cara kerja yang salah ataupun fasilitas kerja yang kurang baik dapat memicu terjadinya permasalahan atau keluhan pada otot atau tulang yang sering disebut Musculoskeletal Disorders (MSD's) (Norlinta et al,2019). Penjahit merupakan pekerjaan yang bergerak pada bidang industri yang dilakukan secara individu maupun sebagai pekerja industri di sebuah pabrik konveksi. Permasalahan MSD's pada penjahit yang sering terjadi adalah kekakuan pada leher, keterbatasan gerak leher dan nyeri pada leher. Hal ini dapat mengakibatkan penurunan aktivitas fungsional leher dan akhirnya menyebabkan sesorang tidak dapat bekerja. Penelitian ini menggunakan desain pre experimental one group pre test-post test design dengan melibatkan 14 responden dengan menggunakan Purposive Sampling. Menggunakan 1 kelompok intervensi yaitu Teknik Snags Mulligan. Hasil uji T Berpasangan 0.000<0.05 sehingga $H_{1}$ diterima. Teknik Snags Mulligan berpengaruh dalam menurunkan gangguan aktivitas fungsional leher pada penjahit di Akina Koveksi Kota Malang.
\end{abstract}

Kata Kunci : Teknik Snags Mulligan, Aktivitas Fungsional Leher, Musculoskeletal Disorders, Penjahit

\section{PENDAHULUAN}

Perubahan ekonomi yang terjadi sekarang ini menyebabkan sektor industri selalu berupaya dan berlomba-lomba untuk meningkatkan produksi. Namun sampai saat ini masih banyak pekerjaan yang dilakukan tanpa mempertimbangkan kesehatan dalam jangka waktu yang panjang. Cara kerja yang salah ataupun fasilitas kerja yang kurang baik dapat memicu terjadinya permasalahan atau keluhan pada otot atau tulang yang sering disebut Musculoskeletal Disorders (MSD’s) (Norlinta et al,2019).

Prevalensi yang didapatkan bderdasarkan Labor Force Survey (LFS) dari kasus MSD's sebanyak 1.144.000 kasus. 493.000 menyerang punggung, 426.000 menyerang leher dan 224.000 kasus pada anggota tubuh bagian bawah (Nurhikmah, 2011).

Penjahit merupakan pekerjaan yang bergerak pada bidang industri yang dilakukan secara individu maupun sebagai pekerja industri di sebuah pabrik konveksi. Penjahit merupakan pekerjaan dengan posisi duduk yang lama, kedua tangan yang selalu berada pada mesin jahit kemudian kedua kaki menginjak sadel penggerak dinamo, serta posisi leher yang cenderung miring ke arah depan. Jika posisi ini dilakukan dalam waktu yang lama dapat menimbulkan permasalahan MSDs seperti nyeri pada leher dan keterbatasan gerak pada leher (Wulandari et al, 2017).

Secara fungsional leher merupakan bagian tubuh yang paling aktif bergerak setelah tangan dan kaki. Pada leher juga 
sering terjadi perubahan beban yang disebabkan oleh adanya perubahan posisi kepala dan postur. Dikarenakan leher merupakan salah satu bagian tubuh yang paling aktif maka kemungkinan leher mengalami cidera atau permasalahan MSD's pun menjadi besar (Sudaryanto et al, 2013).

Permasalahan MSD's pada penjahit yang sering terjadi adalah kekakuan pada leher, keterbatasan gerak leher dan nyeri pada leher. Hal ini dapat mengakibatkan penurunan aktivitas fungsional leher dan akhirnya menyebabkan sesorang tidak dapat bekerja (Wahyuningsih, 2017). Aktivitas fungsional leher adalah kemampuan seseorang untuk melakukan atau menggerakan lehernya yang meliputi gerakan menoleh, gerakan memutar kepala dan gerakan menunduk secara mandiri. Aktivitas fungsional leher sangat dipengaruhi oleh beberapa faktor, yaitu lingkup gerak sendi leher dan nyeri pada leher (Wahyuningsih, 2017).

Untuk menangani permasalahan ini dapat dapat menggunakan manual terapi. Metode manual terapi yang efektif pada kasus vertebra khususnya leher adalah teknik Snags Mulligan. Pada penelitian yang dilakukan oleh (Gautam et al, 2014) membuktikan bahwa untuk meningkatkan lingkup gerak sendi leher, mengurangi nyeri leher dan meningkatkan fungsional leher lebih baik dengan menggunakan teknik Mulligan. Sustained Natural Apophyseal Glides (SNAGs) merupakan salah satu teknik Mulligan untuk mengatasi permasalahan di daerah cervical, thoracal serta lumbal. Teknik ini diaplikasikan dengan posisi weight bearing serta arah mobilisasinya sejajar dengan bidang gerak dari facet joint. Fasilitasi pada glide harus dilakukan secara penuh tanpa ada rasa nyeri yang timbul (Wahyuningsih, 2017).

\section{HASIL DAN PEMBAHASAN}

Penelitian ini menggunakan desain pre experimental one group pre test-post test design dengan melibatkan 14 responden dengan menggunakan Purposive Sampling. Menggunakan 1 kelompok intervensi yaitu Teknik Snags Mulligan. Karakteristik data dari responden berdasarkan usia pada penjahit di Akina Konveksi Kota Malang yang berjumlah 14 responden:

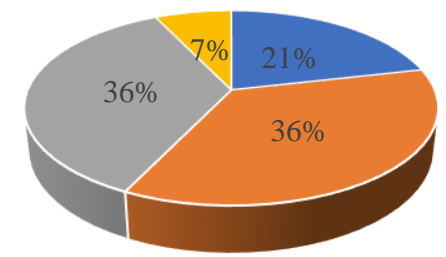

- 17-25 Tahun $\approx$ 26-35 Tahun

-36-45 Tahun $₫$ 46-55 Tahun

Diagram 1 Karakteristik Responden berdasarkan Usia

(Sumber : Data Pribadi, 2020)

Menurut diagram 1 menyatakan bahwa responden terbanyak adalah dengan usia 36-45 tahun sebanyak 5 orang (36\%), usia 26-35 tahun sebanyak 5 orang (36\%), usia 17-25 tahun sebanyak 3 orang (21\%) dan usia 46-55 tahun sebanyak 1 orang (7\%). Ganggua MSDs paling sering terjadi pada usia 30-60 tahun, dikrenakan pada saat usia tersebut kemampuan dari otot mengalami penurunan serta semakin usia bertambah maka otot akan mengalami proses degenerasi yang menyebabkan masa dan jumlah serabut otot berkurang (Anggraeni, 2013).

Karektertistik data responden berdasarkan jenis kelamin: 


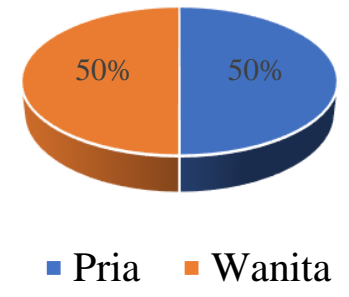

Diagram 2 Karakteristik Responden

Berdasarkan Jenis Kelamin

(Sumber: Data Pribadi, 2020)

\begin{tabular}{|c|c|c|c|c|}
\hline \multicolumn{5}{|c|}{ Paired T Test } \\
\hline Judul & Df & $\begin{array}{c}\text { P } \\
\text { Value }\end{array}$ & $\begin{array}{c}\text { T } \\
\text { Hitung }\end{array}$ & $\begin{array}{c}\text { T } \\
\text { Tabel }\end{array}$ \\
\hline Teknik & 13 & 0,000 & 11,015 & 1,771 \\
Snags & & & & \\
Mulligan & & & & \\
\hline
\end{tabular}

Berdasarkan diagram 2 menunjukan hasil jumlah responden pri dan wanita memiliki jumklah yang sama. Pada penelitian yang dilakukan oleh (Delgado et al, 2009) menyebutkan bahwa 54\% masalah MSDs diderita oleh perempuan dan laki-laki hanya 45\%. Hal ini dikarenakankemapuan otot dari wanita lebih rendah dari pria (Marhaeni, 2016).

Karakteristik data responden berdasarkan masa kerja:

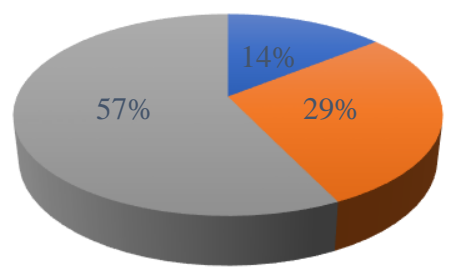

-1-3 Tahun $₫$ 4-6 Tahun $\square$ >6 Tahun

Diagram 3 Karakteristik Responden

Berdasarkan Masa Kerja

(Sumber: Data Pribadi, 2020)

Berdasarkan diagram 3 menunjukan data jumlah responden terbanyak adalah dengan masa kerja lebih dari 6 tahun yaitu sebanyak 8 orang, kemudian responden dengan masa kerja 4-6 tahun sebanyak 4 orang dam responden dengan masa kerja 13 tahun sebanyak 2 orang. Semakin lama masa kerja seseorang dalam bekerja akan menyebabkan seseorang memiliki resiko MSDs semakin tinggi pula, hal ini dikarenakan MSDs lebih sering terjadi karena akumulasi dari trauma-trauma kecil sampai besar yang terjadi secara continue atau terus menerus dalam waktu yang lama (Icsal, 2016).

Hasil dari uji pengaruh yang yang menggunakan uji $\mathrm{T}$ berpasangan adalah sebagai berikut:

Tabel 1 Uji T Berpasangan

(Sumber : Data pribadi, 2020)

\begin{tabular}{lc}
\hline & Sig \\
\hline Teknik Snags Mulligan & 0.00 \\
\hline
\end{tabular}

Berdasarkan hasil dari uji pengaruh menggunakan uji paired t test didapatkan nilai signifikansi sebesar 0,000 dimana nilai tersebut kurang dari atau lebih kecil dari 0,05 yang berarti terdapat pengaruh dari intervensi teknik snags mulligan terhadap penurunan gangguan aktivitas fungsional leher.

Pengaruh dari teknik Snags Mulligan adalah terjadi rileksasi pada otototot antagonis saat dilakukan secara intermiten. Peregangan ini akan menstimulasi golgi tendon sehingga menimbulkan efek placebo (rasa nyaman), kemudian kontraksi pada otot leher, serta stretching yang dilakukan secara intermiten pula akan memperbaiki sirkulasi kapiler dan cairan pada sendi agar menjadi lebih baik dengan latihan aktif sehingga dapat mengurangi iritasi pada saraf afferent yang dapat menimbulkan reflek keseimbangan pada tonus otot, sehingga nyeri dapat berkurang (Norlinta et al., 2019). 
Lesi facet joint cervical akibat postur tubuh yang jelek pada umumnya sering menyebabkan minor positional fault pada permukaan facet joint akibatnya akan terjadi keterbatasan gerak pada cervical secara fisiologis.. Minor fault position atau yang sering disebut minor subluksasi dapat diperbaiki atau dikoreksi dengan menggunakan teknik snags mulligan. Menurut Gong (2013), mobilisasi Snags mempengaruhi dalam peningkatan accessory gliding facet joint cervical. Secara khas, teknik sangs mulligan ini mengombinasikan antara gerak asesori juga dengan gerak fisiologis leher secara aktif maupun pasif, mobilisasi aksesori ini selalu diberikan pada sudut yang sejajar dengan facet joint (Norlinta et al., 2019).

Teknik sangs mulligan ini dapat mengembalikan atau memperbaiki minor fault position pada permukaan facet joint dan mengembalikan kebebasan pergerakan asesoris facet joint sehingga dapat meningkatkan kebebasan gerak fisiologis leher (Sudaryanto et al., 2013).

Jika nyeri berkurang atau bahkan hilang maka secara otomatis lingkup gerak sendi pada leher akan meningkat dan juga kekuatan otot pada leher akan meningkat, hal ini akan berpengaruh dan menyebabkan peningkatan pada kemampuan aktivitas fungsional leher seseorang (Norlinta et al., 2019).

\section{KESIMPULAN}

Pada penelitian yang telah dilakukan ini terdapat kesimpulan yaitu:

1. Terdapat gangguan aktivitas fungsional leher pada penjahit di Akina Konveksi Kota Malang.

2. Teknik Snags Mulligan berpengaruh dalam menurunkan gangguan aktivitas fungsional leher pada penjahit di Akina Koveksi Kota Malang.

\section{DAFTAR PUSTAKA}

Anggraeni, N.C. (2013). Penerapan Myofascial Release Technique sama Baik dengan Ischemic Compression Technique dalam Menurunkan Nyeri pada Sindroma Miofasial Otot Upper Trapezius. Skripsi. Denpasar: Universitas Udayana.

Delgado, Vázquez, E., Romero, J.C., and Escoda, C.G. (2009). Myofascial Pain Syndrome Associated with Trigger Points: A Literature Review. (I): Epidemiology, clinical treatment and etiopathogeny. Journal section: Oral Medicine and Pathology Publication Types: Review.

Gautam, R., Dhamija, J. K., \& Puri, A. (2014). Comparison Of Maitland And Mulligan Mobilization in. International Journal of Physiotherapy and Research, Vol 2(3):482-87.

Marhaeni. (2016). Keputihan pada Wanita. The Journal of Health: Poltekes Denpasar. 13(1).

Norlinta, S. O., Kuswardani, R. T., Imron, M. A., Ketut, T., Adiputra, N., \& Irfan, M. (2019). Teknik Mulligan Paling Efektif Dibandingkan MobilisasiSegmental Untuk Peningkatan Kemampuan Fungsional pada Pembatik Tulis Dengan Cervical Syndrome. Sport and Fitness Journal, 19-27.

Nurhikmah. (2011). Faktor-faktor yang Berhubungan dengan Muskuloskeletal Disorders (MSDs) pada Pekerja Bagian Furnitur di Kecamatan Benda Kota Tangerang. Skripsi Ilmiah, Universita Islam Negeri Syarif Hidayatullah Jakarta. 
Sudaryanto, Sutjana, P. D., \& Irfan, M. (2013). Pemberian Teknik Mulligan dan Soft Tissue Mobilization Lebih Baik dari pada Hanya Soft Tissue Mobilizati Dalam Meningkatkan Lingkup Gerak Sendi Ekstensi, Rotasi, Lateral Fleksi Cervical Pada Mechanical Neck Pain. Sport and Fitness Journal, Volume 1, No. 2 : $54-69$.

Wahyuningsih, N. W. (2017). Efektivitas Mulligan Mobilization Dan Infrared Dengan Myofascial Release Technique Dan Infrared
Terhadap Peningkatan Lingkup Gerak Sendi Nyeri Leher Non Spesifik Pada Penjahit di Kecamatan Kuta. Skripsi. Tidak Diterbitkan. Fakultas Kedokteran. Universitas Udayana : Bali.

Wulandari, D. R., Moelyaningrum, A. D., \& Hartanti, R. I. (2017). Risiko Ergonomi Dan Keluhan Muskuloskeletaldisorders Pada Pekerja Jahit (studi di ud. ilfa jaya konveksi banyuwangi-indonesia). Prosiding Seminar Dalam Rangka OSH week, 119-13. 
